\title{
MEDICINE
}

\section{ДИНАМІКА МОРФОЛОГІЧНИХ ЗМІН СТРУКТУРНИХ КОМПОНЕНТІВ ХРЯЩОВОГО ПОКРИТТЯ КОЛІННОГО СУГЛОБА НА УЛЬТРАСТРУКТУРНОМУ РІВНІ НА СУБХРОНІЧНОМУ ТА ХРОНІЧНОМУ ПЕРІОДАХ ЕКСПЕРИМЕНТАЛЬНОГО ОПІОЇДНОГО ВПЛИВУ НАПРИКІНЦІ ЧЕТВЕРТОГО, П'ЯТОГО ТА ШОСТОГО ТИЖНІВ}

\author{
Войценко К. І., Пальтов С. В., Фік В. Б., Кривко Ю. Я. \\ Львівський національний медичний університет імені Данила Галищького, кафедра нормальної \\ анатомії, м. Львів
}

DOI: https://doi.org/10.31435/rsglobal_sr/28022019/6365

\section{ARTICLE INFO}

Received 27 December 2018 Accepted 18 February 2019

Published 28 February 2019

\section{KEYWORDS}

opioid,

chondrodystrophy,

experimental,

rat.

\begin{abstract}
The work, presented below, aimed at studying the dynamics of structural disorganization of morphological components of the articular cartilage at ultrastructural level in subchronic and chronic periods of experimental opioid chondrodystrophy. The purpose was achieved by ultrastructural visualization of the components of the articular cartilage. Generally accepted conventional methods were used for obtaining microstructural material.

The results of the study will form pathomorphological basis, which can be applied for the development of diagnostic criteria for lesions of the articular cartilage at different stages of opioid exposure. Furthermore, pathomorphological findings will form the basis for effective medical handling of opioid chondrodystrophy of the articular cartilage and its consequences.
\end{abstract}

Citation: Войценко К. І., Пальтов С. В., Фік В. Б., Кривко Ю. Я. (2019) Dynamika Morfolohichnykh Zmin Strukturnykh Komponentiv Khriashchovoho Pokryttia Kolinnoho Suhloba na Ultrastrukturnomu Rivni na Subkhronichnomu ta Khronichnomu Periodakh Eksperymentalnoho Opioidnoho Vplyvu Naprykintsi Chetvertoho, Piatoho ta Shostoho Tyzhniv. Science Review. 2(19). doi: 10.31435/rsglobal_sr/28022019/6365

Copyright: (C) 2019 Войценко К. І., Пальтов С. В., Фік В. Б., Кривко Ю. Я. This is an open-access article distributed under the terms of the Creative Commons Attribution License (CC BY). The use, distribution or reproduction in other forums is permitted, provided the original author(s) or licensor are credited and that the original publication in this journal is cited, in accordance with accepted academic practice. No use, distribution or reproduction is permitted which does not comply with these terms.

Результати статі відповідають плану наукових досліджень Львівського національного медичного університету імені Данила Галицького і є частиною науково - дослідної теми кафедри нормальної анатомії «Структурна організація, ангіоархітектоніки та антропометричні особливості органів у внутрішньо та позаутробному періодах розвитку, за умов екзо- та ендопатогених факторів» (номер держреєстрації 0115U000041) впродовж 2015 - 2019 pp.

Вступ. Згідно статистичних даних з джерел зарубіжної та вітчизняної морфологічної літератури, патологія хрящової, кісткової та сполучної тканини формує широку групу серед населення молодого та зрілого віку[1,2]. Процес грунтовного вивчення поведінки структурних компонентів хрящового покриття суглобів в експериментальній морфології має значне теоретичне, що в подальшому буде формувати важливе практичне значення в основі розробки нових методів діагностики та лікування проблем даної ділянки. В літературних джерелах 
висвітлюються результати досліджень, що присвячені патоморфологічним змінам в тканинах та органах при неконтрольованому вживанні опіоїдних середників медичного та кустарного виробництва $[3,4]$. Незважаючи, що у доступній фаховій вітчизняній та зарубіжній літературі існують повідомлення про патоморфологічні зміни у ряді органів та систем на тлі опіоїдного впливу [5 - 17], і досі лишається нез'ясованим питання, що до проявів токсичної хондропатії на підгрунті опіоїдного впливу та динаміку появи та наростання дегенеративних змін структурних компонентів хрящового покриття колінного суглобу на гострій, субхронічній та хронічній фазі перебігу експериментального опіоїдного впливу.

Вищезазначене окреслело мету нашої роботи, що полягала у вивченні особливостей патоморфологічних змін ультраструктурної організації хрящового покриття колінного суглоба у субхронічній та хронічній фазі впливу опіоїдного анальгетика в експерименті.

Матеріали та методи дослідження. Матеріалом дослідження слугували статево зрілі, безпородні щури-самці в кількості 32-ві тварини, масою 112 - 135 г, віком 4,5 місяців. Тваринам проводили ін'єкції препарату налбуфін дом'язево, щоденно 1 раз на добу в одному проміжку часу (10-11 година ранку) впродовж 21 доби. Початкова доза налбуфіну становила 8 мг/кг впродовж першого тижня, 15 мг/кг впродовж другого тижня, 20 мг/кг впродовж третього тижня, 25 мг/кг впродовж четвертого тижня, 30 мг/кг впродовж п'ятого тижня та 35 мг/кг впродовж шостого тижня, таким чином створювали умови хронічного опіоїдного впливу [18]. Тварини поділені на 4 групи. 1-а група тварин отримувала налбуфін протягом 28 діб в одному проміжку часу (10 - 11 годин ранку) з наступним забором матеріалу дослідження (кінець 4-го тижня експериментального опіоїдного впливу); 2-а група тварин отримувала налбуфін протягом 35 діб в одному проміжку часу (10-11 годин ранку) з наступним забором матеріалу дослідження (кінець 5-го тижня експериментального опіоїдного впливу); 3-а група тварин отримувала налбуфін протягом 42 діб в одному проміжку часу (10 - 11 годин ранку) 3 наступним забором матеріалу дослідження (кінець 6-го тижня експериментального опіоїдного впливу); 4 - а контрольна, яка протягом 42 діб отримувала ін'єкції фізіологічного розчину дом'язево в одному проміжку часу (10-11 годин ранку). Усі тварини знаходились в умовах віварію і робота, що стосувалася питань утримання, догляду, маркування та всі інші маніпуляції проводилися із дотриманням положень «Європейської конвенції про захист хребетних тварин, які використовуються для експериментальних та інших наукових цілей» [Стразбург, 1985], “ Загальних етичних принципів експериментів на тваринах ”, ухвалених Першим Національним конгресом з біоєтики [Київ, 2001]. Комісією з біоєтики Львівського національного медичного університету імені Данила Галицького встановлено, що проведені наукові дослідження відповідають етичним вимогам згідно наказу МО3 України № 231 від 01.11.2000 року ( протокол № 10 від 26.12.2011 року). Перед проведенням забору біопсійного матеріалу тварину присипляли дибутиловим ефіром. Як матеріал для ультраструктурного дослідження використали хрящі дистального епіфізу стегнової та проксимального епіфізу великогомілкової кісток колінного суглоба щурів. Ультраструктурні препарати готували за загальноприйнятою методикою [19-21].

Результати дослідження. В результаті ультраструктурного дослідження клітинного складу хрящового покриття колінного суглоба експериментальної групи тварин наприкінці 28ої доби у шурів, що знаходилися під впливом опіоїдного анальгетика в дозі 25 мг/кг на ультраструктурному рівні нами було виявлено, що суглобова поверхня була нерівною, у поверхневій зоні кількість хрящового матриксу збільшувалась, хондроцити розташовувались нещільно. У хондроцитах проміжної та базальної зони реєстрували розвиток дегенеративних та некротичних змін, а також апоптозу. У багатьох хондроцитах проміжної зони відзначали розширення цистерн гладкої, рідше гранулярної ендоплазматичної сітки, нагромадження чисельних вакуолей, що були заповнені різним за осміофільністю вмістом як це показано на рис. 1 , рис. 2 , рис.3. 


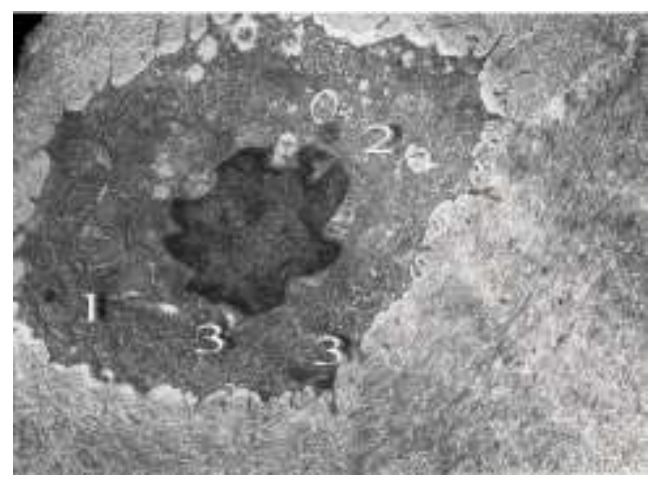

Рис. 1. Хондрочит проміжної зони хряща колінного суглоба щура наприкінці 28-ої доби опіоїдного впливу. Мікрофотографія. 3б. х 8000.

1 - розиирення цистерн гладкої ендоплпзматичної сітки; 2 - підвищена осміофільність цитоолазми; 3 -руйнування крист мітохондрій.

Поодинокі мітохондрії були збільшені в об’ємі, і їх кристи частково або повністю лізовані, мітохондріальний матрикс різко просвітлювався, з формуванням електронно-прозорих вакуолей.

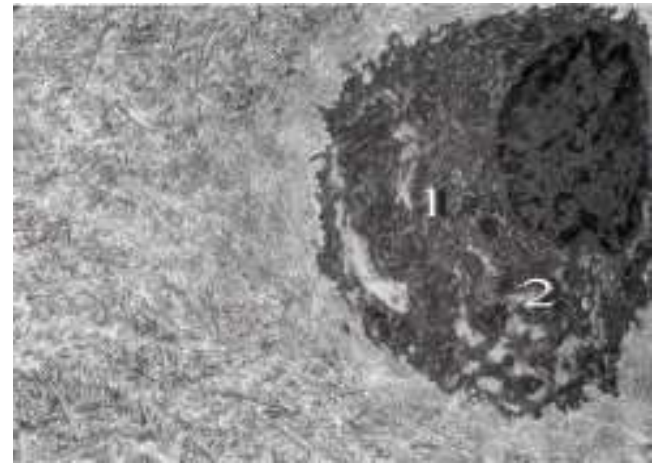

Рис. 2. Хондроцит перехідної зони хряща колінного суглоба щура наприкінці 28-ої доби опіоїдного впливу. Мікрофотографія. 3б. х 6000.

1 - розширення цистерн гладкої ендоплпзматичної сітки; 2 - деструкиія рибосом гранулярної ендоплазматичної сітки.

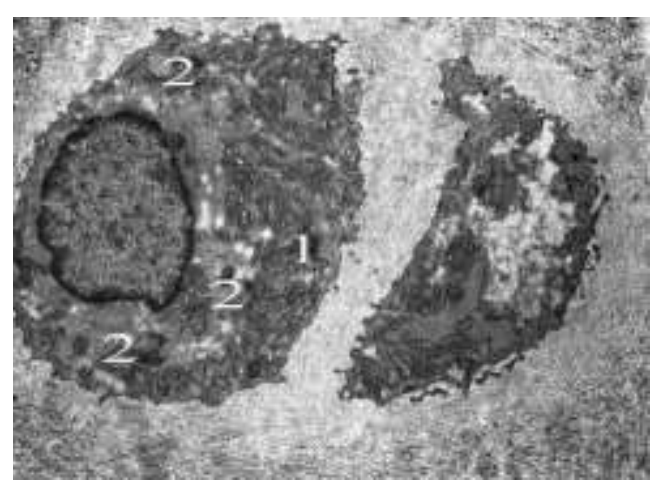

Рис. 3. Хондроџит перехідної зони хряща колінного суглоба щура наприкінці 28-ої доби опіоїдного впливу. Мікрофотографія. 3б. х 6000.

1 - значне розширення ичистерн гладкої ендоплпзматичної сітки; 2 - деструкиія ичттоплазматичних органел.

У хондроцитах перехідної зони також відзначали розвиток некротичних змін як це видноно на рис.4, рис.5. Ядро у таких хондроцитів набувало неправильної форми, ущільнювалось, було заповнене переважно не гетерохроматином. Поруч із зруйнованими хондроцитами відзначали лізіс колагенових волокон. Місцями візуалізувались лакуни заповнені неоднорідним переважно електронносвітлим вмістом. Відзначали деструкцію органел та ділянки локального лізісу плазматичної мембрани. 


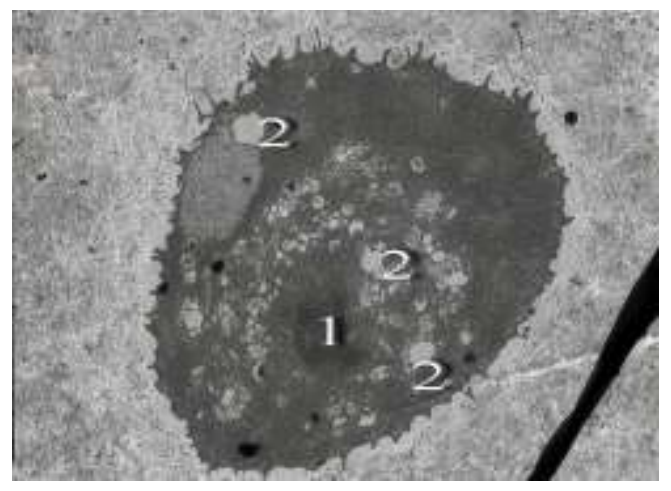

Рис. 4. Некротизований хондрочит перехідної зони хряща колінного суглоба щура наприкінщі 28-ої доби опіоїдного впливу. Мікрофотографія. 3б. х 6000.

1 - каріопікноз; 2 - чисельні вакуолі в циитоплазмі.

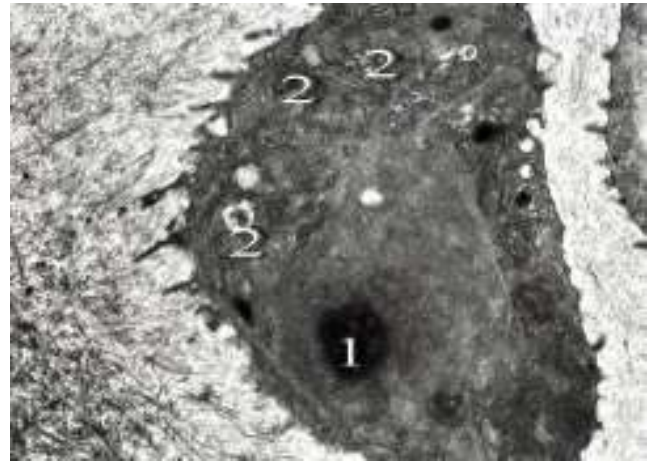

Рис. 5. Некротизований хондрощит перехідної зони хряща колінного суглоба щура наприкінщі 28-ої доби опіоїдного впливу. Мікрофотографія. 3б. х 6000.

1 - каріопікноз ядра; 2 - практично повна деструктуризачія органел.

Слід зазначити, що окрім хондроцитів в яких розвивались дистрофічні та некротичні зміни у поверхневій та проміжній зоні зустрічались хондроцити із збереженою структурою та 3 підвищеною функціональною активністю. Зокрема візуалізувались хондроцити ядра яких містили значну кількість еухроматину, цитоплазматичні органели були збережені, візуалізувався комплекс Гольджі та розширені цистерни гранулярної ендоплазматичної сітки, що містили білковий вміст. Рибосоми у таких хондроцитах були збережені. У цитоплазмі також візуалізувався комплекс Гольджі, секреторні вакуолі, ліпідні включення, зерна глікогену. У поодиноких мітохондріях збережених хондроцитів перехідної зони матрикс мав дрібнозернисту структуру та середню електронну щільність, і лише подекуди відзначали його просвітлення. Окремі кристи мітохондрій були вкорочені. Міжтериторіальний матрикс перехідної зони був неоднорідним, здебільшого просвітленим. Фібрили колагенових волокон розташовувались хаотично, відзначали розширення міжфібрилярних проміжків. Фібрили колагенових волокон втрачали поперечну посмугованість, розпадались на окремі фрагменти як це показано рис.6. Траплялись ділянки на яких фібрили колагенових волокна були лізовані.

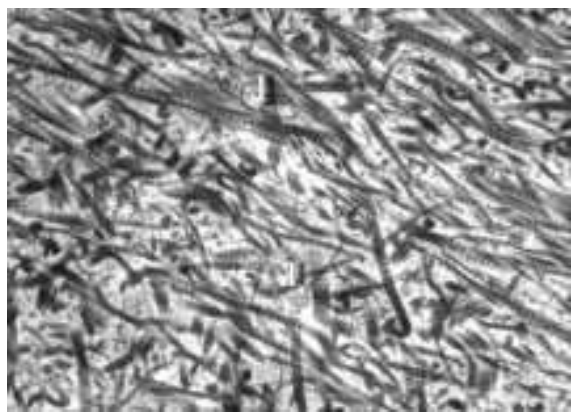

Рис. 6. Хаотичне зозташування колагенових волокон хряща колінного суглоба щура наприкінці 28-ої доби опіоїдного впливу. Мікрофотографія. 3б. х 12000.

1 - руйнування фібрил колагенових волокон. 
В периферичних зонах суглобового хряща відзначали неоднорідне потовщення колагенових волокон. У ділянках на яких збільшувався об’єм хрящового матриксу траплялись безклітинні зони.

В результаті проведеного забору експериментального матеріалу наприкінці 35-ої доби у шурів, що знаходилися під впливом опіоїдного анальгетика в дозі 30 мг / кг на ультраструктурному рівні нами було виявлено, що в товщі суглобового хряща виникало неоднорідне потовщення фібрил колагенових волокон безклітинної пластинки та збільшення об’єму хрящового матриксу. На суглобовій поверхні траплялись невеликі заглиблення та вертикальні тріщини суглобової поверхні. В таких ділянках хрящовий матрикс був неоднорідним, просвітленим, фібрили колагенових волокон зазнавали лізісу. У перехідній зоні також збільшувався об'єм між територіального хрящового матриксу. Відзначали його неоднорідне забарвлення: чергувались ділянки просвітлення, із зонами нагромадження інтенсивноосміофільних мас. Фібрили колагенових волокон розташовувались хаотично. Відзначали неоднорідне потовщення колагенових волокон. Унаслідок збільшення об'єму хрящового матрикса хондроцити розташовувались нещільно. У хондроцитах перехідної зони відзначали наростання дегенеративних змін, зустрічались хондроцити в стані некрозу та апоптозу. У дегенеративно змінених хондроцитах відзначали значне розширення цистерн гладкої ендоплазматичної сітки як це видно рис.7. фрагментацію та лізіс іiі мембран. Спостерігали значну деструкцію органел цитоплазми як це показано рис.8. За умов розвитку некротичних змін хондроцитів перехідної зони, окрім каріопікнозу як це видно рис.9., відзначали різке просвітлення цитоплазми, нагромадження у ній чисельних вакуоль.

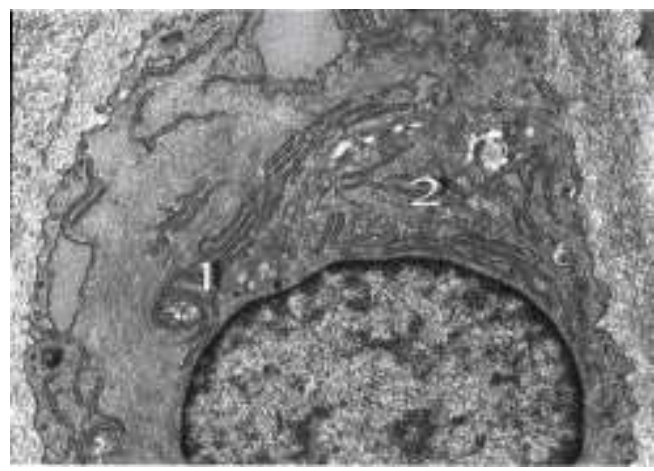

Рис. 7. Хондроџит прехідної зони хряща колінного суглоба щура наприкінці 35-ої доби опіоїдного виливу. Мікрофотографія. 3б. х 14000.

1 -розширення цистерн гладкої ендоплазматичної сітки; 2 - фрагментація та руйнування мембран ендоплазматичної сітки.

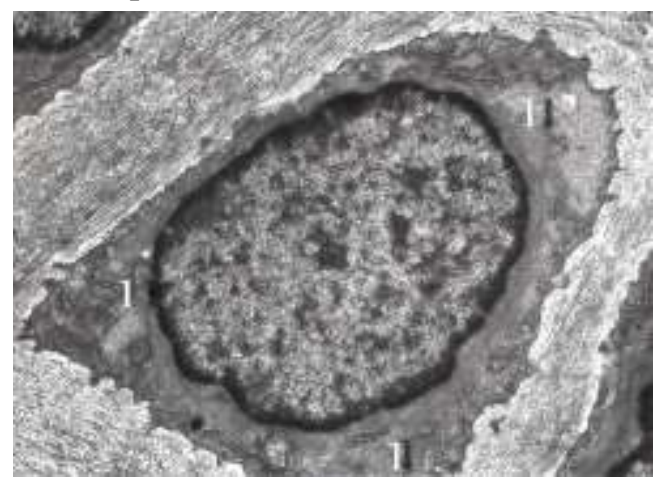

Рис. 8. Хондрочит прехідної зони хряща колінного суглоба щура наприкінщі 35-ої доби опіоїдного виливу. Мікрофотографія. 3б. х 12000.

1 - деструкція органел цичтоплазми хондроцита перехідної зони

Під час апоптозу хондроцити зменшувались в об’ємі, зморщувались, втрачали контакт 3 територіальним матриксом та сусідніми хондроцитами. У ядрі відзначали конденсацію хроматину. Цитоплазма різко просвітлювалась. Після руйнування цитоплазматичної мембрани вміст цитоплазми потрапляв до розширеної лакуни. Перицелюлярний матрикс у таких ділянках здебільшого ущільнювався, ставав інтенсивноосміофільним. 


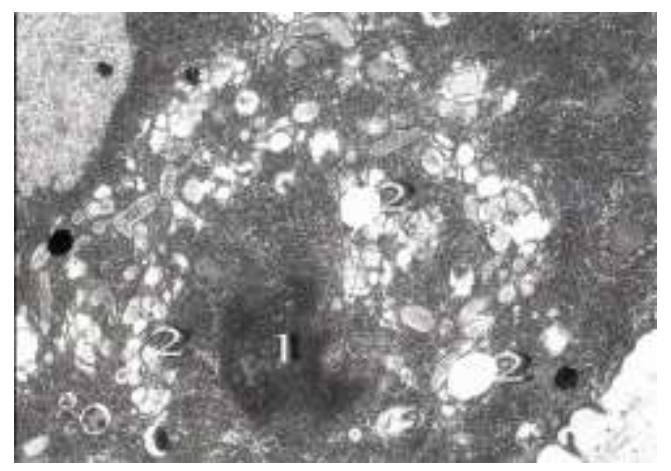

Рис. 9. Некроз хондроцита перехідної зони хрящза колінного суглоба шура наприкінці 35 -ої доби опіоїдного впливу. Мікрофотографія. Зб. х 6000.

1 - каріопікноз ядра хондроцита; 2 - вакуолізація циитоплазми.

У променистій зоні виявили яскраво виражену вакуольну дистрофію багатьох хондроцитів, а також їх некротичні зміни. Зокрема, в цитоплазмі хондроцитів променистої зони відзначали різке розширення цистерн гладкої та гранулярної ендоплазматичної сітки. Профілі гранулярної ендоплазматичної сітки майже не містили рибосом та були переповнені вакуолями, що супроводжувалось тотальною деструкцією органел та нагромадження жирових включень та зерен глікогену. Ядро зазнавало вираженого пікнозу як це показано рис.10.

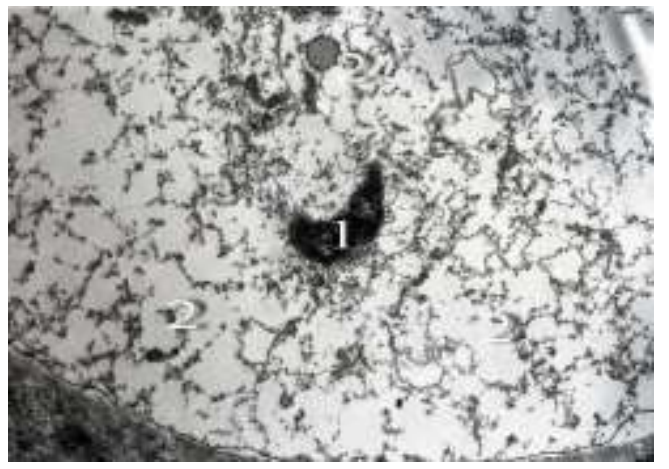

Рис. 10. Некроз хондроцита променистої зони хряща колінного суглоба щура наприкінці 35-ої доби опіоїдного впливу. Мікрофотографія. Зб. х 6000.

1 -каріопікноз; 2 - різке просвітлення цитоплазми; 3 - деструкція органел.

У ділянках збільшення об'єму основної речовини хрящового матриксу хондроцити перехідної та променистої зон розташовувались невпорядковано, не відзначали стовпчастого розташування. В цих ділянках переважало острівцеве розташування клітин. Фігури мітозів хондроцитів зустрічались надзвичайно рідко. Місцями формувались вогнища радіально та хаотично розташованих хондроцитів у центрі яких локалізувалась помірна кількість безструктурної неоднорідноосміофільної маси. На значних ділянках відзначали збільшення кількості та потовщення фібрил колагенових волокон як це видно рис.11. У таких ділянках збільшувалась кількість безклітинних зон. У субхондральній зоні відзначали появу кісткових виростів, по периферії яких розташовувались активні остеобласти, із світлим еухроматиновим, ексцентрично розміщеним ядром, що містило добре виражене ядерце, а також цитоплазматичні органели синтезу. Зокрема, поблизу ядра містився добре виражений комплекс Гольджі, що містив вакуолі та везикули. Майже увесь об'єм цитоплазми займала гранулярна ендоплазматична сітка, з чисельними рибосомами та білковим вмістом у широких цистернах. Також у цитоплазмі зустрічались вільні рибосоми та полісоми, дрібні лізосоми та секреторні гранули, мітохондрії з кристами помірної висоти та інтенсивноосміофільним матриксом, а по периферії матриксні міхурці, що відіграють важливу роль у процесах мінералізації. 


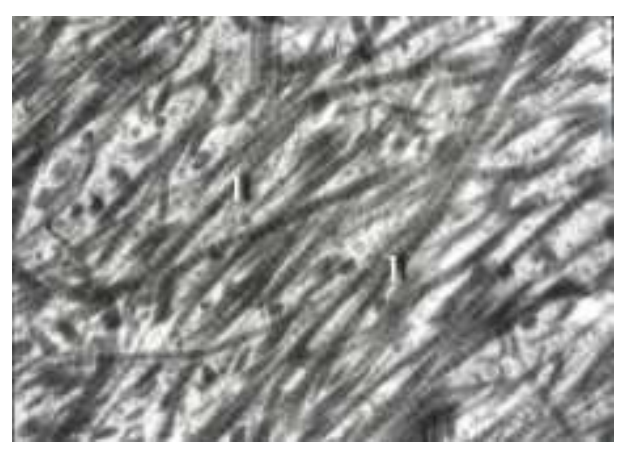

Рис. 11. Базальна зони хряща колінного суглоба щура наприкінщі 35-ої доби опіоїдного впливу.

Мікрофотографія. Зб. х 18000.

1 - потовщення фібрил колагенових волокон.

Активні остеобласти, в таких ділянках, тісно прилягали одні до одних. Також відзначали трансформацію остеобластів у молоді остеоцити витягнутої форми, з світлим еухроматиновим ядром, компактною гранулярною ендоплазматичною сіткою, вкритою рибосомами. Поблизу ядра в цитоплазмі молодих остеоцитів локалізувався комплекс Гольджі. Місцями зустрічались мітохондрії та лізосомоподібні структури, нечисельні полісоми. Від поверхні молодих остеоцитів відходили чисельні короткі відростки, що проникали в матрикс, який містив значну кількість новоутворених фібрил колагенових волокон. В результаті проведеного забору експериментального матеріалу наприкінці 42-ої доби у шурів, що знаходилися під впливом опіоїдного анальгетика в дозі 35 мг/кг на ультраструктурному рівні нами було виявлено дезорганізацію матриксу, а у хондроцитах дегенеративні, некротичні зміни, а також розвиток апоптозу. На суглобовій поверхні досить часто траплялись заглиблення, глибокі дефекти, що супроводжувалось розволокненням та руйнуванням фібрил колагенових волокон поверхневої зони. Значне збільшення об'єму хрящового матриксу відзначали у всіх зонах суглобового хряща. У багатьох хондроцитах перехідної зони відзначали збільшення кількості гетерохроматину в ядрі як це показано рис.12, 13, 14. та значну деструкцію органел цитоплазми.

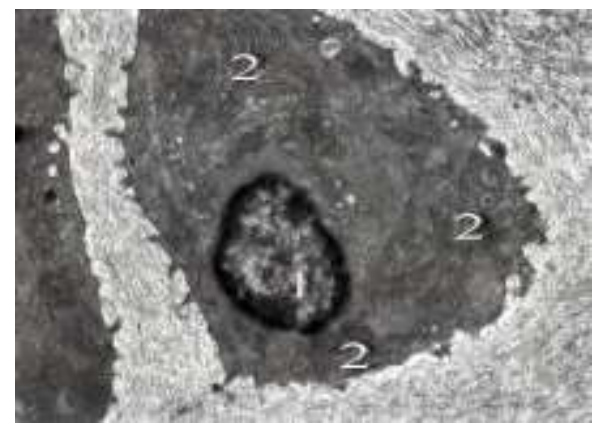

Рис. 12. Хондроцит перехідної зони хряща колінного суглоба щура наприкінці 42-ої доби опіоїдного впливу. Мікрофотографія. 3б. х 8000.

1 - збільшення кількості гетерохроматину в ядрі; 2 - деструкція органел циитоплазми.

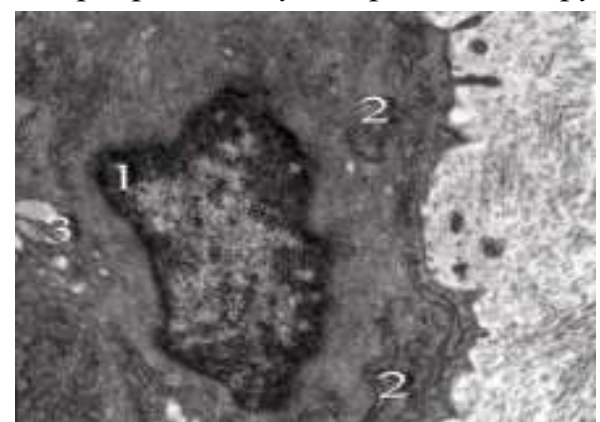

Рис. 13. Хондроцит перехідної зони хряща колінного суглоба щура наприкіниі 42-ої доби опіоїдного впливу. Мікрофотографія. 3б. х 8000.

1 - амебоїдна інвангінація ядра; 2 - повна деструкція органел циитоплазми; 3 - вакуолізаиія изитоплазми. 


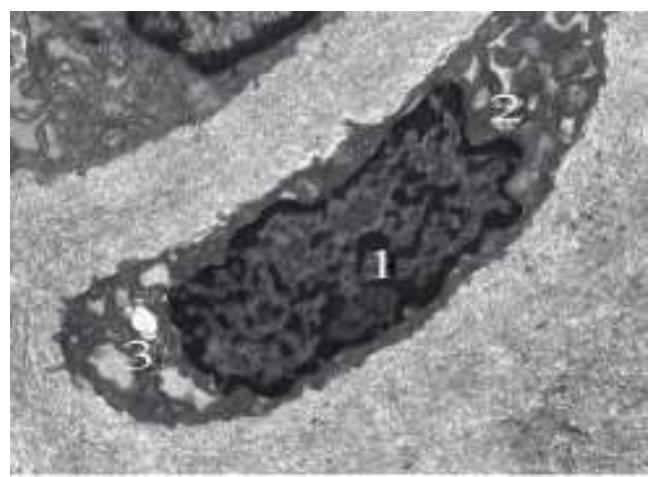

Рис. 14. Хондроцит перехідної зони хряща колінного суглоба щура наприкінщі 42-ої доби опіоїдного впливу. Мікрофотографія. 3б. х 6000.

1 - збільшення кількості гетерохроматину в ядрі; 2 - розширення канальців гладкої ендоплазматичної сітки; 3 - вакуолізація циитоплазми та деструкція її органел.

Присутні ділянки візуалізації фрагментів некротизованих хондроцитів як це видно рис. 15 , хрящового покриття колінного суглоба, рідко траплялись хондроцити із збереженою структурою.

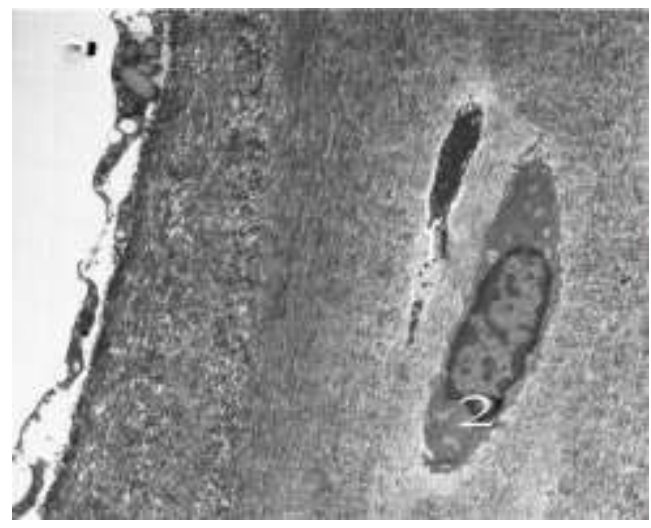

Рис. 15. Хондроцит перехідної зони хряща колінного суглоба щура наприкінці 42-ої доби опіоїдного впливу. Мікрофотографія. 3б. х 4000.

1 - фрагменти некротизованого хондроцита; 2 -хондроцит із збереженою структурою.

У неоднорідноосміофільному матриксу перехідної зони збільшувалась кількість колагенових волокон. Відзначали потовщення фібрил колагенових волокон. Хондроцити розташовувались нещільно. Досить часто траплялись безклітинні зони. У перехідній та базальній зонах відзначали просвітлення матриксу, з руйнуванням фібрил колагенових волокон. У таких ділянках візуалізувались хондроцити 3 вираженою просвітленою цитоплазмою. Зустрічались лакуни, що містили світлу осміофільну рідину та залишки однорідних інтенсивноосміфільних ядер. Траплялись хондроцити у стані “темноклітинної загибелі” як це показано рис.16. Також візуалізувались фрагменти некротизованих хондроцитів як це видно рис.17. Матрикс навколо загиблих хондроцитів просвітлювався.

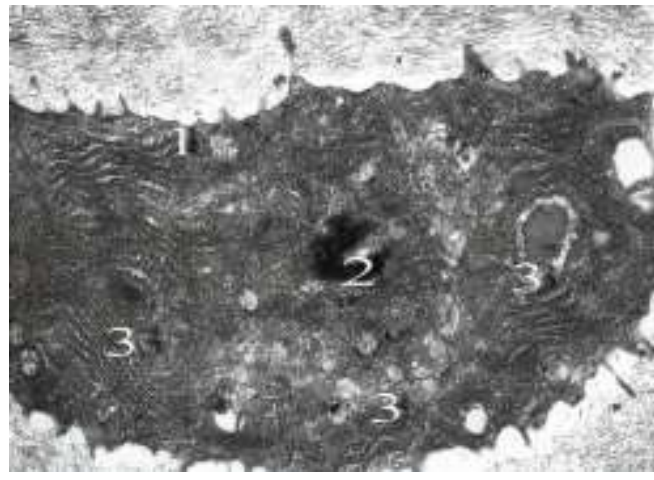

Рис. 16. Хондроцит перехідної зони хряща колінного суглоба шура наприкінці 42-ої доби опіӧ̈дного виливу. Мікрофотографія. 3б. х 6000.

1 - некротизація хондроцита; 2 - каріопікноз; 3 - деструкція органел циттоплазми. 


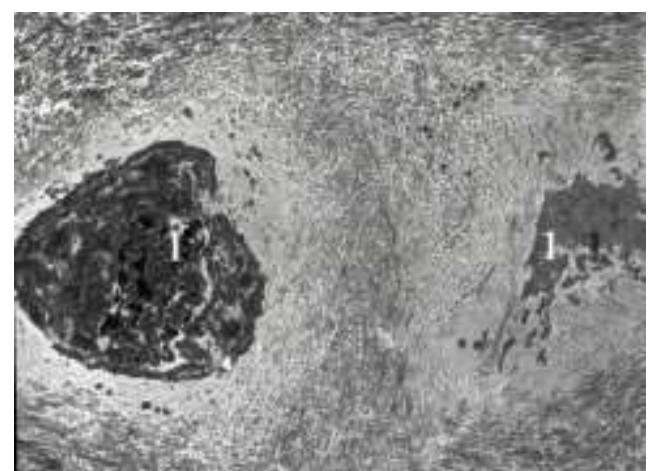

Рис. 17. Хондроцит перехідної зони хряща колінного суглоба щура наприкінці 42-ої доби опіоїдного впливу. Мікрофотографія. Зб. х 6000.

1 - фрагменти некротизаиії хондроцитів.

Траплялись збережені хондроцити, ізогенні групи зустрічались рідко. У субхондральних ділянках траплялись ділянки 3 неоднорідним інтенсивноосміофільним матриксом, збільшувалась кількість остеоїдної тканини, фронт осифікації був нерівним.

Висновки. 1. Наприкінці четвертого тижня експериментального опіоїдного впливу нами виявлені у хондроцитах проміжної та базальної зони процеси розвитку дегенеративних та некротичних змін, а також апоптозу. У багатьох хондроцитах проміжної зони відзначали розширення цистерн гладкої, рідше гранулярної ендоплазматичної сітки та нагромадження чисельних вакуолей.

2. Наприкінці п'ятого тижня експериментального опіоїдного впливу у хондроцитах перехідної зони відзначали наростання дегенеративних змін, що супроводжувалося масовими явищами некрозу та апоптозу. У дегенеративно змінених хондроцитах відзначали значне розширення цистерн гладкої ендоплазматичної сітки. Прогресували процеси фрагментації та лізису іiі мембран. Спостерігали значну деструкцію органел цитоплазми. За умов розвитку некротичних змін хондроцитів перехідної зони, окрім каріопікнозу, відзначали різке просвітлення цитоплазми та нагромадження у ній чисельних вакуоль.

3. Наприкінці шостого тижня експериментального опіоїдного впливу нами було виявлено дезорганізацію матриксу, а у хондроцитах дегенеративні, некротичні зміни, а також розвиток апоптозу. На суглобовій поверхні досить часто траплялись заглиблення, глибокі дефекти, що супроводжувалось розволокненням та руйнуванням фібрил колагенових волокон поверхневої зони. Значне збільшення об’єму хрящового матриксу відзначали у всіх зонах суглобового хряща. У багатьох хондроцитах перехідної зони відзначали збільшення кількості гетерохроматину в ядрі та значну деструкцію органел цитоплазми. Всі зазначені процеси мали характер наростаючих та агресивних хондродегенеративних змін.

\section{ЛІТЕРАТУРА}

1. Dudina, O. O., \& Tereshchenkov, A. V. (2014). Situational analysis of children's health status. Bulletin of Social Hygiene and Health Care Organizations of Ukraine, 2, 49-57.

2. Adrashkin, A. P, Salomatin, I. V, \& Murashov, B. F. (2003). The role of the cardiovascular system in thanatogenesis in opiate addicts of the second stage. From research to treatment standards: Newsletter on the Russian national Congress of Cardiology. Moscow: Russian Society of Cardiology, 18.

3. Raietska, L. V. (2008). Trends in the spread of drug addiction in Ukraine. Fighting organized crime and corruption, 18, 67-76.

4. Treshchinskiy, I. S., Kharchenko, L. A., \& Usenko, V. A. (1998). Some issues of drug addiction and substance abuse in Ukraine. Pharmacist, 4, 15-17.

5. Logash M., \& Pokotylo P. (2013). Some aspects of the history of opiates in the context of nowadays drug addiction problems. Bulletin of Biology and Medicine, 4-1 (42), 129-131.

6. Yakimiv N.Y. (2014). Ultrastructural characteristics structures prismatic-corneal angle eyeball rats after opioid exposure. World of Medicine and Biology, 2 (44), 185-188.

7. Yakimiv NY. (2014). Ultrastructural characteristics of irido-corneal angle of eye of rats on $7^{\text {th }}, 14^{\text {th }}, 21^{\text {st }}$ and $28^{\text {th }}$ days of opioid influence. Ukrainian morphological almanac, 2, 28-31.

8. Paltov Ye.V. (2004). Morphological features of the anatomy of the arterial bed of the neck and maxillofacial area of the rat are normal. Scientific herald of the SZ Gzhytsky Lviv National Academy of Veterinary Medicine, 6-1(1), 113-119. 
9. Paltov Ye.V. (2004). Roengenoanatomy of the arteries of the rat head and neck. Clinical anatomy and operative surgery, 3 (2), 26-29.

10. Paltov Ye.V., Kryvko Yu.Ya., Tomashova S.A., Vil'hova I.V., \& Matkivskyi R.M. (2006). The state of microstructural organization of soft tissues of periodontal disease in white rats in norm and their change at different stages of the course of experimental streptozotocin diabetes mellitus. Bulletin of the Sumy State University, 2 (86), 36-43.

11. Paltov Ye.V., \& Kryvko Yu.Ya. (2006). The ultrastructural organization of soft tissues of periodontal disease in white rats is normal and the dynamics of their changes during the course of streptotsotocininduced experimental diabetes mellitus. World of Medicine and Biology, 3, 35-44.

12. Paltov Ye.V., Chelpanova I.V., Fik V.B., Vil'hova I.V., Kyryk Kh.A., \& Kryvko Yu.Ya. (2017). Pathomorphological changes in layers of retina for six weeks of opioid exposure experiment. World of Medicine and Biology, 2 (60), 146-150.

13. Paltov Ye.V., \& Kryvko Yu.Ya. (2017). Pathological changes in the layers of the retina after eight weeks of opioid influence at the experiment. Bulletin of problems biology and medicine, 4-2 (140), 118-122.

14. Paltov Ye.V., Fik V.B., \& Kryvko Yu.Ya. (2018). Pathomorphological changes in the retina layer at the end of the fourth week of opioid effect, Natural Science Readings abstracts booc. Sosnowiec-Bratislava, 30-32.

15. Fik V.B., Paltov E.V., Lohash M.V., \& Kryvko Yu.Ya. (2017). Pecularities of morphological manifestation of the periodontal tissue in experimental animals against the ground of a short-term effect of opioid analgesic. Deutsch. Wissenscaftsch, 2, 54-58.

16. Fik V.B., Kryvko Yu.Ya., \& Paltov E.V. (2018). Microstructural changes of periodontal tissue under the action of opioid analgesics in the early stages. Bukovinian Medical Herald, 22-1 (85), 141-148.

17. Fik V.B., Paltov E.V., \& Kryvko Yu.Ya. (2018). Morphofunctional peculiarities of the periodontal tissue under conditions of simulated eight-week opioid effect. Deutscher Wissenschaftscherold German Science Herald, 1, 14-17. DOI:10.19221/201814.

18. Onisco, RM, Paltov, YV, Fik, VB, Fitkalo, OS. (2013). Ukraine. Patent No. 76564. Kyiv: Ukrainian Institute of Intellectual Property (Ukrpatent).

19. Glauert A.M. (1975). Fixation, Dehydration and Embedding of Biological Specimens. In: Practical methods in electron microscpi. North-Hollond: American Elsevier.

20. Stempak J.G., \& Ward R.T. (1964). An improved staining method for electron microscopy. J Cell Biol, 22 (3), 697-701.

21. Reynolds E.S. (1963). The use of lead citrate at high $\mathrm{pH}$ as an electronopague stain in electron microscopy. J Cell Biol, 17, 208-212. 